\title{
Mencari Teater Modern Indonesia Versi Asrul Sani: Penelusuran Pascakolonial
}

oleh

Taufik Darwis

Alumni Jurusan Teater STSI Bandung

Mahasiswa Pascasarjana Ilmu Religi dan Budaya Universitas Sanata Dharma Yogyakarta taufik.darwis@yahoo.com

\begin{abstract}
Asrul Sani, along with Chairil Anwar and Rivai Apin, may sound familiar and renowned in literature, in spite of theatre, as one of the major literary figures of Angkatan '45. Asrul Sani's name might be known widely by the theatre activists and actors only as a translator. His name is observed because it is often cited in the translated drama text which is selected to be played. Those who are more observant and seriously wanted to explore their ability in acting will also find his name in the elderly book about acting methodology belongs to one of the Russian theatrical figures - again as a translator. Perhaps, we are practically unconcern about why his name is frequently cited as a translator in dramatic literature and our theatre, because we never seem to have dispute with the practice of translation itself. Therefore, the writing is directed to investigate and discover the substance that become the fundamental of his idea in the translation practice, and biographically, to disclose Asrul Sani's influence (his consideration) toward the development of Indonesian theatre nowadays.
\end{abstract}

Key words: Indonesian modern theater, postcolonial

\begin{abstract}
ABSTRAK
Asrul Sani, sama seperti Chairil Anwar dan Rivai Apin, mungkin terdengar tidak asing dan sangat terkenal dalam bidang sastra, selain teater, sebagai salah satu tokoh sastra utama dari Angkatan '45. Nama Asrul Sani mungkin dikenal secara luas oleh para aktivis teater dan para aktor hanya sebagai penerjemah. Namanya diperhatikan karena sering dikutip dalam teks drama terjemahan terpilih untuk dimainkan. Mereka yang lebih jeli dan secara serius ingin mengeksplorasi kemampuan mereka dalam berakting juga akan mendapatkan namanya dalam buku tua tentang metodologi akting milik salah seorang tokoh teater Rusia - juga sebagai penerjemah. Mungkin, secara praktis kita tidak peduli mengapa namanya sering disebut sebagai penerjemah dalam literatur drama dan teater kita, karena tampaknya kita tidak pernah melakukan perdebatan dengan praktek penerjemahan itu sendiri. Oleh karena itu, penulisan ini diarahkan untuk menyelidiki dan menemukan substansi yang menjadi dasar idenya dalam praktek penerjemahan, dan secara biografis, untuk mengungkap pengaruh (pertimbangan) Asrul Sani terhadap perkembangan teater di Indonesia saat ini.
\end{abstract}

Kata kunci: Teater modern Indonesia, pascakolonial 


\section{PENDAHULUAN}

Pelaku teater mana yang tidak kenal AsrulSani? Banyak! Pertanyaan danjawaban ini jarang atau malah mungkin sama sekali tidak akan terdengar di ranah teater saat ini, sepeninggal masa-masa apa yang disebut "teater sutradara"dan minimnya forum-forum teater yang menggalakkan pengayaan pemikiran. ${ }^{1}$ Padahal kalau kita jeli membaca, "Teater Modern Indonesia versi Asrul" masih sangat berpengaruh dalam berbagai praktik di dalam pergaulan teater, khususnya di Perguruan Tinggi Seni, atau di dalam kelompok-kelompok teater dengan ideologi estetik dan kultural tertentu yang dipengaruhinya. Hipotesa ini mungkin dirasa konyol atau terlalu menyederhanakan, tapi di sisi lain tulisan ini juga dibuat untuk berusaha menjawab anggapan penulis sendiri yang juga ada di dalam ranah tersebut. Tulisan ini tidak akan membahas sejarah teater modern Indonesia versi lain, misalnya versi yang digalakkan oleh IDRF (Indonesia Dramatic Reading Festival) yang menggunakan buku Antologi Naskah Drama Indonesia 1-4 yang diterbitkan Yayasan Lontar di mana di dalamnya terdapat semacam hipotesa besar Sapardi Joko Damono, bahwa Teater Indonesia: "Sebermula Adalah Realisme". Kenapa? Karena buku ini terlambat hadir dan tidak terlalu terlembagakan di dalam praktik pergaulan teater, apalagi di Perguruan Tinggi Seni.

Sebaliknya, Asrul Sani, disadari atau tidak, pengaruh pandangan kultural dan ideologi estetiknya yakni bagaimana seharusnya teater modern Indonesia (secara langsung atau tidak), berpengaruh sampai saat ini (meskipun sudah bercampur baur secara majemuk). Khususnya, naskah drama terjemahan, metode akting teater realis
(Stanislavsky), dan pembentukan lembaga kesenian (teater dan film) yang masih begitu terasa tertanam di ranah pergaulan teater. Hal ini disebabkan karena karyakarya terjemahan dari naskah drama sampai metode pelatihan aktingnya masih tetap dipelajari dan diproduksi, meskipun namanya mungkin saja hanya dikenal sebagai penerjemah. Sebelum beranggapan lebih jauh, untuk meretas sekaligus menjawab, penulis mencoba menguraikan secara singkat siapa Asrul Sani ini. ${ }^{2}$

\section{Biografi Singkat Asrul Sani}

Asrul Sani, lahir di Rao, di bagian utara Sumatra Barat pada tanggal 10 Juni 1927. Ayahnya raja adat setempat bergelar Sutan Marah Sani Syair Alamsyah Yang Dipertuan Sakti Rao Mapat yang membawahi empat orang raja-upeti. Ia adalah anak kedua dari dua bersaudara. Asrul hidup berpindah-pindah dari Rao ke Lubuk Sikaping dan Bukit Tinggi untuk bersekolah sampai belajar di HIS (SD dengan pengantar bahasa Belanda), meskipun tidak disetujui ayahnya. Ketika orang tuanya pindah ke Bukit Tinggi, Asrul mulai membeli bukubuku dari uang yang didapat dari ibunya, dan akhirnya ia menjadi gemar membaca. Selain itu ia juga aktif sebagai pembaca di perpustakaan yang terdapat di Bukit Tinggi, khususnya buku-buku terbitan Balai Pustaka. Pengayaan membacanya juga ditambah lagi dari koleksi buku pamannnya yang tidak terdapat di perpustakaan, yaitu buku tentang pergerakan nasional. Pada tahun 1939 ayahnya wafat, lalu pada tahun itu juga setamat HIS ia masuk ke KWS (Koningin Wilhelmina School) Sekolah Teknik Jakarta. Setelah merasa dirinya tidak berbakat di sekolah teknik dan ketika bala tentara Jepang masuk ke Indonesia, tahun 1941, ia kembali ke Rao. Pada wak- 
tu itulah secara tidak sengaja Asrul menemukan setumpuk buku yang tersimpan di kamar, di antaranya terdapat satu jilid sejarah kesusastraan Yunani dalam bahasa Belanda. Pada titik inilah timbul dorongannya untuk menulis.

Ketika berumur 16 tahun, ia berangkat ke Jakarta untuk sekolah lagi tetapi bukan di sekolah teknik. Asrul masuk Taman Siswa,, dan bertemu dengan Pak Said yang menyukai puisi. Di Taman Siswa ia banyak berjumpa dan bergelut dengan kesusastraan dunia.

Pada masa revolusi ia terlibat dengan perjuangan dalam memperoleh kedaulatan dan bergabung dengan Pasukan 001 yang bertugas di belakang garis musuh dan berpindah ke kota Bogor serta memimpin surat kabar Suara Bogor. Tahun 1950 ia kemudian keluar dari kesatuannya, karena menganggap perjuangan sudah selesai dengan bertepatannya pengakuan kedaulatan oleh Belanda.

Di Taman Siswa, Asrul duduk sebangku dengan Pramoedya Ananta Toer dan di luar sekolah ia berkenalan dengan Chairil Anwar, Rivai Apin, Cornel Simanjuntak, dan seniman yang lain. Bersama Chairil dan lain-lain, ia duduk sebagai redaktur majalah Gema Suasana dan redaktur lampiran kebudayaan "Gelanggang" pada warta sepekan Siasat yang dipimpin Rosihan Anwar dan Soejatmoko, dan pernah juga tercantum sebagai anggota redaksi majalah Pujangga Baru, Majalah Indonesia BMKN (Badan Musyawarah Kebudayaan Nasional), dan majalah Zenith yang dipimpin oleh H.B Yassin.

Meskipun Asrul terlibat di beberapa surat kabar, tapi di Gelanggang-lah ia benar-benar terlibat langsung, dan mengundurkan diri dari berbagai keterlibatannya yang lain sejak tahun 1956. Di Gelanggang bersama Chairil dan Apin, ia menerbitkan berbagai kumpulan sajak yang kemudian disebut sebagai pelopor Angkatan '45 dalam perpuisian Indonesia, dan mereka merumuskan konsep keseniannya yang kemudian terkenal sebagai Surat Kepercayaan Gelanggang. Mereka akhirnya berpisah arah. Chairil meninggal dunia tahun 1949. Basuki, Apin, dan Henk kemudian menjadi anggota aktif di Lekra yang berpaham kiri. Asrul dan Usmar Ismail mendirikan Lesbumi (Lembaga Seniman Budayawan Muslimin Indonesia) yang berinduk pada partai Nahdatul Ulama. AdapunSitor Situmorang yang pernah membela Angkatan ' 45 kemudian mendirikan LKN (Lembaga Kebudayaan Nasional) yang berinduk pada PNI (Partai Nasional Indonesia).

Setelah itu Asrul melanjutkan sekolahnya ke Perguruan Tinggi Kedokteran Hewan di Bogor dan selesai tahun 1955. Akan tetapi minatnya pada kesenian mengalahkan minatnya pada bidang studinya. Tahun 1952 ia diundang oleh Sticusa (Yayasan Kerjasama Kebudayaan Belanda) untuk belajar tentang teater di Akademi Seni Drama Ansterdam, dan belajar tentang bloking pentas dan teori-metode akting Stanilavsky. Tahun 1954, ia berperan dalam pembentukan MSDR (Masyarakat Seniman Djakarta Raya). Di tahun yang sama juga ia berangkat ke Amerika Serikat karena diundang oleh Universitas Harvard untuk menghadiri seminar kebudayaan dan tinggal bersama dengan grup Playwright Theatre. Sepulang dari Amerika, pada tahun 1955, bersama Usmar Ismail dan D. Djajakusuma, Asrul mendirian ATNI (Akademi Teater Nasional Indonesia). Tahun 1956 Asrul berangkat lagi ke Amerika untuk mempelajari dramaturgi dam sinematografi di University of 
Siuthern California dan sepulang di sana ia mendirikan Persari (Persatuan Artis Republik Indonesia). Pada masa Demokrasi Terpimpin (1959-1965), Asrul banyak diserang oleh orang-orang kiri. Tahun 1968 seniman Jakarta diundang oleh Gubernur Ali Sadikin untuk membuat wadah kegiatan kesenian, Asrul terpilih sebagai seorang formatur dan duduk sebagai Dewan Kesenian Jakarta (DKJ) pertama (1968-1970) sekaligus menjadi aggota Akademi Jakarta (AJ), dan menggantikan Umar Kayam dalam mempimpin IKJ (Institut Kesenian Jakarta) dan pembentukan TIM (Taman Ismalil Marzuki). Di masa inilah Asrul banyak menerjemahkan sastra atau lakon drama dunia untuk kepentingan berbagai macam program.

\section{Surat 'Kepercayaan Gelanggang' dan Awal Pencarian Teater Asrul}

Seperti yang telah disebutkan di bagian pendahuluan, di dalam ranah pergaulan teater jarang sekali nama Asrul Sani mencuat ke permukaan wacana dan menjadi pembacaan penting bagi gerak sejarah teater Indonesia, selain itu literatur-literatur yang sempat menjadikannya penting hanya menjadi semacam koleksi yang berdebu di perpustakaan pribadi atau lembaga pendidikan seni. Misalnya, salah satu buku yang penting untuk membuka wacana "mencari teater Asrul" adalah buku lebih tepatnya adalah sekumpulan catatan yang terdiri dari makalah-makalah, pembicaraan lisan, dan artikel yang dihasilkan dari pertemuan Forum Teater Naskah Jerman - yang diterbitkan Goethe-Institut Jakarta tahun 1989 dengan judul Beberapa Pemikiran Tentang Pementasan Naskah Barat Oleh Teater Indonesia.

Juga seperti penempatan di dalam buku ini, terdapat tulisan awal dari Jakob
Sumardjo yang dapat menjadi titik awal pencarian teater Asrul, khususnya latar belakang pemikiran yang menjadikannya banyak menerjemahkan sastra drama dunia (Eropa). Jakob Sumardjo dalam tulisannya - karena forum ini membicarakan pementasan naskah Barat oleh Teater Indonesia - menguraikan bagaimana perkembangan terjemahan sastra drama asing dan teater Barat di Indonesia tidak terlepas dari kehadiran Belanda, di mulai dari tahun 1619 (menguasai Jayakarta sampai 1970/1980-an (pasca revolusi). ${ }^{3}$ Ketika dalam masa perkembangan itu terjadi titik persinggungan antara kalangan siswasiswa dokter sekolah dokter Jawa yang bersekolah di sekolah menak dan sekolah calon pegawai pemerintah kolonial (Koemedi Stemboel), bangsawan (opera Derma), kaum terpelajar Cina yang mengkritik kemunduran teater Indonesia sejak Koemedi Stamboel dengan banyak menerjemahkan sastra drama yang beredar di lingkungan teater Belanda juga kaum terpelajar yang ada dilingkungan penulis Boemiputra, dan teater profesional (Miss Roboet's Orion dan Dardanella) yang konsisten memakai naskah asli karena mempunyai penulis tetap dalam pementasannya serta didukung oleh penonton yang berasal dari golongan menengah bawah. Konsistensi ini berlangsung sampai permulaan tahun 1950'an hingga kemudian berubah, setelah pemulihan kedaulatan, hilangnya rombongan teater profesional akibat proses sensor keras semasa pemerintah pendudukan Jepang dan bergesernya orientasi bintang panggung ke bidang perfilman dan makin besarnya minat kaum terpelajar terhadap kegiatan teater.

Dengan semakin lenyapnya teater profesional dan merebaknya teater amatir yang berasal dari kaum terpelajar, juga 
semakin bergesernya fungsi naskah (sastra drama) dalam pementasan teater. Bila rombongan profesional yang lebih banyak mengandalkan kepada spontanitas dan improvisasi seni bermain pada aktornya, sehingga kedudukan sastra drama tidak begitu pokok, teater amatir mutlak berpegangan pada naskah drama untuk main (1989: 13). Hingga muncullah dua lembaga pendidikan teater: 1948 di Yogya didirikan Cine Drama Institut (kemudian menjadi ASDRAFI). Dan di Jakarta, pada tahun 1955 didirikan Akademi Teater Nasinal Indonesia (ATNI) dengan salah satu pendirinya adalah Asrul Sani. Jakob Sumardjo menyebutnya sebagai titik awal "zaman emas" pementasan naskah-naskah asing dan yang menjadi gerbang besarnya adalah kredo "humanisme-universal". Yakni sebuah kepercayaan bahwa persoalan kemanusian terjadi di kebudayaan belahan bumi manapun lalu menjadikan "yang universal" tersebut sebagai warisan dan mereka (Asrul dan Angkatan'45) menyatakan diri dengan sebuah surat: 'Surat Kepercayaan Gelanggang'4, untuk menjadikan mereka sebagai ahli waris yang sah. Di bawah inidisertakan kutipan seluruhnya darisurat itu dengan harapan bisa menemukan celah baru dalam mencari teater modern versi Asrul (1997: 3-4):

"Kami adalah ahli waris yang sah dari kebudayaan dunia dan kebudayaan ini kami teruskan dengan cara kami sendiri.Kami lahir dari kalangan orang banyak dan pengertian rakyat bagi kami adalah kumpulan campur-baur dari mana dunia baru yang sehat dapat dilahirkan.

Keindonesiaan kami tidak semata-mata karena kulit kami yang sawo matang, rambut kami yang hitam atau tulang pelipis kami yang menjorok ke depan, tetapi lebih banyak oleh apa yang diutarakan oleh wujud pernyataan hati dan pikiran kami.

Kami tidak akan memberi kata ikatan untuk kebudayaan Indonesia, kami tidak ingat akan melap-lap hasil kebudayaan lama sampai berkilat dan untuk dibanggakan, tetapi kami memikirkan suatu penghidupan kebudayaan baru yang sehat. Kebudayaan Indonesia ditetapkan oleh kesatuan berbagai-bagai rangsang suara yang disebabkan oleh suara yang dilontarkan kembali dalam bentuk suara sendiri. Kami akan menentang segala usaha yang mempersempit dan menghalangi tidak betulnya pemeriksaan ukuran nilai.

Revolusi bagi kami ialah penempatan nilai-nilai baru atas nilai-nilai usang yang harus dihancurkan. Demikian kami berpendapat, bahwa revolusi di tanah air kami sendiri belum selesai.

Dalam penemuan kami, kami mungkin tidak selalu asli; yang pokok ditemui adalah manusia.Dalam cara kami mencari, membahas, dan menelaahlah kami membawa sifat sendiri.

Penghargaan kami terhadap keadaan keliling (masyarakat) adalah penghargaan orang-orang yang mengetahui adanya saling pengaruh antara masyarakat dan seniman.

Jakarta, 18 Februari 1950"

\section{Teater yang Lahir Dari Kewargaduniaan Asrul?}

“Coba saja pikir, ketika itu kedaulatan Negara baru saja didapatkan setelah sekian lama perjuangan berdarah dan 
diplomasi dijalankan. Belum sampai bernafas lega, tiba-tiba Negara yang masih sangat muda ini menghadapi sekian banyak masalah politik, ekonomi, dan sosial.Di saat seperti itu tiba-tiba pula Asrul tampil dengan sebuah pernyataan yang dengan lantang menggugah kesadaran dan orientasi kultural. Baru saja sebuah batas perjalanan sejarah bangsa berhasil didirikan dengan darah dan air mata, ia tampil dengan pernyataan kultural yang terasa seperti merelatifkan batas itu - "Kami adalah ahli waris yang sah kebudayaan dunia dan kebudayan ini kami teruskan dengan cara kami sendiri". Mengapa tidak mengatakan "ahli waris kebudayaan nenek moyang?" bukankah ini bikin perkara namanya?" (Abdullah, 1997: xiv)

Kalimat tersebut sengaja dikutip dari kata pengantar Taufik Abdullah dalam buku Surat-Surat Kepercayaan ${ }^{5}$ untuk memberi gambaran bagaimana Asrul dan Angkatan' 45 menjadi begitu penting dibicarakan oleh para seniman sebelum dan sesudah generasinya. Abdullah mengatakan bahwa Asrul "bikin perkara" karena mempunyai kesadaran kultural yang percaya untuk berfikir bebas, tapi bukan pada gejala sosio-kultural yang terjadi yakni lahirnya sebuah Negara Indonesia, tapi pada dirinya sendiri. Apakah Asrul memang "bikin perkara"?

Kalau membaca dari uraian biografi singkat di atas, ke-wargadunia-an Asrul dengan kalimatnya "Kami adalah ahli waris yang sah kebudayaan dunia dan kebudayan ini kami teruskan dengan cara kami sendiri" merupakan konsekuensi dari perjalanan birografisnya yang semenjak kecil sampai pendidikan tinggi banyak bersentuhan dengan kesusastraan dunia. ${ }^{6}$ Keith Foulcher dalam esainya "Angkatan ' 45 dan Warisannya"7 mendefinisikan bahwa sastra Angkatan '45 timbul dari hasil karya sekelompok penulis yang aktif pada masa pendudukan Belanda di Jakarta pada tahun 1945. Ungkapan kesusastraan kelompok penulis ini menunjukkan pada adanya asimilasi suatu kecenderungan kesenian dan kesusastraan modernis Eropa di tahun-tahun antara masa peperangan PD I dan II pada kebudayaan Indonesia (1997: 96).

Lalu lebih jauh Foulcher mencoba mencoba mengaitkan sekaligus membedakan Angkatan'45 dengan gerakan nasionalisme Indonesia aliran Sjahrir (pamannya Chairil) yang mengembangkan sebuah kerangka berpikir dan bertindak yang tidak menemui kesulitan dalam merekonsiliasi antara perjuangan gerakan nasionalis bagi kebebasan dan kemerdekaan Indonesia, dengan rasa hormat pada nilai-nilai dan peradaban Barat, yakni pembangunan pola pikir internasional Meskipun pada titik berikutnya Foulcher mengatakan bahwa tidak ada titik persinggungan secara langsung antara gerakan Sjahrir dan Angkatan'45 - :

“Upaya keras bagi taraf pengertian 'internasional' ini menjadi tema utama dalam karya-karya kelompok Chairil Anwar. Ini bukanlah 'internasionalisme' yang ditawarkan Sjahrir dan kelompoknya yang berdasarkan pada suatu kerangka dalam memahami pertentangan antara fasisme dan kapitalisme selama masa pendudukan Jepang.Sebaliknya bagi Chairil dan kelompoknya hal ini berangkat dari identifikasi terhadap estetika modernis Eropa. Ini berarti, ketika digunakan 
oleh Chairil Anwar dan kelompoknya, kerangka 'internasional' ini menempati tanggung jawab penuh pada integritas individu seniman/intelektual sebagai 'pembangunan kebudayaan'." (1997:93-94)

Nasionalisme Kebudayaan - atau kata Abdullah "warisan nenek moyang" atau dalam bahasa Asrul "melap-lap hasil kebudayaan lama sampai berkilat dan untuk dibanggakan"- itu dielakkan karena mengaburkan tanggung jawab individual. Karena menurut Asrul "yang pokok ditemui adalah manusia". Jadi apa hubungannya ke-wargadunia-an Asrul dan Angkatan'45 ini "yang pokoknya ditemui adalah manusia" dengan pencarian teater modern (versi Asrul) yang akan dibaca dalam perspektif pascakolonial ini?

\section{Pemikiran Teater Asrul}

Sebelum lebih jauh pada pembahasan mengenai bagaimana Asrul bergulat dengan pemikirannya sendiri mengenai teater, yang nantinya melahirkan beberapa peristiwa penting bagi teater modern Indonesia (dalam versinya), di bawah ini disertakan (lagi) kutipan beberapa pemikirannya untuk membawa pemahaman lebih pada letak dasar pikirannya dalam memposisikan teater. Demikian juga signifikansinya bagi kepercayaan pada ke-wargadunia-an "yang tidak akan memberi kata ikatan untuk kebudayaan Indonesia", dan "tidak ingat akan melap-lap hasil kebudayaan lama sampai berkilat dan untuk dibanggakan", tetapi "memikirkan suatu penghidupan kebudayaan baru yang sehat". Di bawah ini ${ }^{8}$ adalah kutipannya:

“Salah satu hal yang paling banyak dipersoalkan di Negara-negara baru berkembang - termasuk kawasan Asia Tenggara - adalah persoalan identitas diri dan pencarian identitas baru. Persoalan ini adalah persoalan manusia dengan keadaan sekitarnya, persoalan kondisi manusia dalam suatu zaman. Dan jika orang yang mempersoalkan ini mengarahkan pandangannya pada sejarah maka akan ia rasakan dengan keras kekosongan yang terdapat dalam sejarah kebudayaan Indonesia yang saya gambarkan tadi. Ia akan menginginkan sejarah kebudayaan sebagai sejarah umat manusia. Akan, kelihatan bahwa pemikiran sejarah dalam rangka ratusan tahun tidaklah menolong, bahkan dapat menyesatkan. (Asrul, 1997:242)

[...]

Memang tidak mudah untuk mengisi kekosongan yang terasakan terdapat dalam gambaran sejarah Kebudayaan Indonesia ini. Tidak adanya kronik-kronik atau catatan harian yang diperlukan untuk ini sangat mempersulit pekerjaan peneliti atau pengarang. Tapi jika bergerak ke zaman yang leih dekat, misalnya ke abad 19, artinya ke wilayah sejarah modern, maka kemungkinan ini akan lebih ada. (1997: 243)

[...]

Jika kebudayaan dipikirkan sebagai pola kehidupan yang dipelajari bersama dan diikuti bersama oleh anggota masyarakat, maka jelaslah bahwa dalam memikirkan sesuatu rangsangan selalu mempergunakan contoh atau "model".Kekosongan ini harus diisi oleh salah satu lembaga yang terdapat dalam sistem kebudayaan tersebut. Dan di Indonesia lembaga itu adalah 
teater" (Ibid: 244).

Di dalam kutipan di atas, jelaslah bahwa implikasi dari pendirian ke-wargaduniaan dan pengutamaannya kepada manusia berpengaruh di dalam pemikirannya tentang teater yang dijadikannya model untuk mengisi "kekosongan dalam sejarah kebudayaan Indonesia", untuk menjawab "persoalan identitas" sebagai manusiaanggota masyarakat dari Negara yang baru merdeka di bawah bayang-bayang politik internasional. Sebab masa-masa kemunculan pemikirannya masih ada di dalam gejolak "keperkaraan" pandangannya dalam Surat Kepercayaan Gelanggang.

Kasus penerjemahan lebih dari 100 judul naskah sastra drama (yang tercatat) ini dapat membuktikan konsistensinya sebagai individu yang mempercayai apa yang diperjuangkannya. Meskipun disadari atau tidak mempunyai jejak keterpengaruhan dari semasa interaksinya dengan pergaulan kalangan intelektual Belanda. Pemikiran tentang penerjemahan naskah ini penulis dapatkan dan kutip dari dalam salah satu esainya (1997: 216):

“Konperensi Teater Internasional yang kira-kira dua bulan lalu diadakan, juga bersamaan dengan itu diadakan Konperensi Penggemar Teater. Tidak dalam ikatan UNESCO, tapi dengan bekerjasama erat dengannya. Inggris mengirim ketua British Drama League dan ahli-ahli sandiwara lain untuk berbicara dalam koperensi penggemar sandiwara ini.

[...]

Maka untuk saat ini ada baiknya jika di Indonesia didirikan sebuah liga seni drama yang berusaha dalam kemajuan-kemajuan seni drama. Salah satu soal yang musykil pada kita sekarang ini ialah tidak adanya atau sangat sedikitnya karangan-karangan sandiwara yang dikarang oleh pengarang-pengarang Indonesia.

[...]

Tapi kekurangan ini dapat kita isi dengan mengadaptasi drama-drama luar negeri.Dan ini adalah kewajiban yang patut di liga ini.Banyak orang mengatakan bahwa kita mempunyai bakat yang besar untuk bermain sandiwara. Tapi permainan sandiwara juga menghendaki teknik dan teknik harus dipelajari. Jika Liga Drama ini hendak didirikan, sedapat mungkin janganlah ia didirikan dengan hubungan pemerintah". ${ }^{9}$

Bisa dibilang, kutipan di atas inilah titik awal keputusannya untuk banyak menerjemahkan naskah-naskah dunia sebagai representasi golongan pelajar dengan teater amatirnya yang gandrung kepada naskah-naskah Barat-dunia yang sudah dibahas melalui tulisan Jakob Sumardjo dalam sub-bab di atas. Tapi tidak hanya itu, Asrul juga dalam kutipan tersebut sudah memikiran tentang pembentukan lembaga kesenian khususnya di Jakarta yang nantinya menjadi ATNI, DKJ, dan IKJ. Tentang penerjemahanan dan pembentukan lembaga kesenian terebut, juga diterangkan Ajip Rosidi dalam catatan penyuntingan Surat-Surat Kepercayaan: "Ketika DKJ menyelenggarakan proyek menerjemahkan lakon dan sastra dunia, Asrul banyak mengambilnya. Saya, ketika menjadi salah seorang Ketua DKJ, pernah menghitung, ternyata lakon dan roman yang telah diterjemahkan oleh Asrul lebih dari 100 (seratus) judul" (Ajip, 1997: viii).

Ania Lomba dalam buku Kolonialismel 
Pascakolonialisme menaruh pentingnya naskah-naskah literer yang bisa dikatakan jauh dari, atau bahkan kritis terhadap, ideologi-ideologi kolonial, bisa dibuat menjadi mengabdi kepentingan-kepentingan kolonial melalui sistem-sistem edukasional yang mendevaluasi literatur-literatur pribumi, dan melalui praktik-praktik kritis Eropa-sentris yang berkeras bahwa naskah-naskah Barat tertentu merupakan pertanda budaya yang lebih unggul. (Lomba, 2000:112). Apakah Asrul menilai sastra drama yang diterjemahkannya itu unggul? Di salah satu esainya yang lain, kepercayaannya akan individu-manusia yang kuat walaupun dianggap-menganggap golongan minoritas juga menjadi penting dalam pemikirannya:

"Juga dalam bidang teater, golongan baru ini menumbuhkan teater yang baru. Jika kita merasa perlu juga untuk mengklasifikasikannya, maka teater ini dapat digolongkan pada teater yang dibangun atas dasar teater Barat. Relatif teater ini baru, namun ia berkembang dengan cepat sekali dan perkembangannya berlangsung di seluruh pelosok Nusantara. Yang jadi paling penting dari fenomena baru ini ialah bahwa ia tidak lagi bertujuan menjadikan dirinya sumber citra yang harus dijadikan contoh oleh orang banyak. Ia tidak menampilkan Arjuna dan Gatotkaca yang dapat dijadikan bahan bagi orang tua dalam mendidik anak-anaknya. Ia terutama mengemukakan hubungan antar manusia dan kenyataan waktu dan tempat.Ia tidak berpikir normatif; yang ideal dapat diomongkan tapi harus diperhitungkan adalah kenyataan yang sebenar-benarnya. Dewa-dewa yang bertubuh manusia diganti dengan manusia yang sebenarnya dengan segala kemungkinan dan kemustahilannya, dan hak-haknya untuk memperjuangkan bentuk hidup atas dasar kebenaran sendiri". (Asrul, 1997:252)

Asrul dengan tegas mengatakan dalam kutipan esai ini: Teater Barat. Teater Barat yang dimaksudkan Asrul adalah teater yang memanggungkan manusia oleh manusia, yang percaya pada manusia. Juga sastra drama yang percaya pada manusia, bukan sosok lain di luar manusia. Manusia yang berada dibelahan bumi manapun. Karena yang paling penting adalah pesan, amanat, dan makna drama yang dapat terjadi di mana saja. Asrul lebih jauh menerangkan lebih jelas:

“Tidak. Jika saya bicara teater dan pendidikan masyarakat, maka tidaklah saya maksud teater mempengaruhi, teater sebagai propaganda, tapi teater yang dijadikan alat untuk kepentingan pembebasan jiwa manusia, pendekatan rakyat dengan zaman dan realitas zamannya sendiri. tragic interealitet-idee. Bukan teater yang memberikan pelajaran, tapi alat komunikasi yang mengutarakan perasaan dan pikiran. (Asrul, 1997:237)

[...]

Teater ini diberikan predikat modern atau kontemporer, oleh umum ia diberikan kehormatan untuk secara resmi memakai predikat seni dalam arti tinggi; ia mulai dipelajari; kaum cendekiawan menaruh perhatian padanya; kaum muda tertarik olehnya; dalam dirinya terkandung potensi yang besar untuk tumbuh. Tapi pada saat ini ia merupakan teater golongan minoritas. Sekiranya bangsa kita menemui manusia dan 
menaikkannya ke atas panggung, maka dalam teater ini manusia itu bukan lagi tipe tapi individu.Teater ini menjadi alat untuk memahami manusia dengan lebih baik.Teater ini mengakui kekhususan setiap pribadi.Teater ini adalah teater demokrasi baru, dan emansipasi manusia modern.Teater yang memilih dan membebaskan diri dari hukum yang menyemaratakan setiap manusia. Sebagai teater yang muda ia belum mampunyai tradisi. Tidak dapat diingkari bahwa bentuk teater ini orientasinya masih ke Eropa dan Amerika. Dalam usahanya untuk mencari bentuk, maka pengertian modern diukur dengan pengertian modern Eropa". (Asrul, 1997: 265)

Kepercayaannya pada manusia sebagai subjek ini juga berpengaruh pada penerjemahannya di luar naskah sastra drama, yaitu teknik-teknik pemeranan atau akting yang juga mempercayai manusia: Stanilavsky ${ }^{10}$ yang menekankan psikologi individu pada masalah-masalah sosial, yang kemudian penerjemahannya diterbitkan oleh Pustaka Jaya. Seperti diterangkan Ajip:

"Karena minat Asrul terpusat pada dunia pentas, sebelum masuk kedunia film - walaupun saatnya mungkin hampir bersamaan. Pada awal tahun 1950-an, tulisan-tulisannya masih suara dari kejauhan, tetapi kemudia menjadi lebih menyatu dengan kegiatan teater ia bersama Usmar Ismail mendirikan Akademi Teater Nasional (ATNI) yang sehari-hari ia pimpin. Asrul juga pernah mendapat kesempatan untuk mempelajari teater di Amerika, membawa gagasan teater yang berdasarkan kebenaran psikologis yang dimulai oleh Konstantin Stanislavsky dan besar pengaruhnya terhadap kelompok teater Actors Studio di New York yang pada waktu itu mencapai masa jayanya. Asrul sendiri kemudian menerjemahkan karya utama Stanislavsky, Persiapan Seorang Aktor (Pustaka Jaya, 1979). Metode akting itu dipraktekan Asrul dengan para mahasiswanya dalam pementasan karya-karya terjemahan. Dari lembaga ini kemudian lahir para aktor, aktris, dan sutradara Indonesia andalan seperti Ismed M. Noor, Tatiek Malyati, Steve Liem (Teguh Karya), Wahyu Sihombing, Pramana Padmodarmaja, dan lain-lain". (1997: x)

Selain pemikirannya tentang penerjemahan sastra drama, teori-metoda akting, dan infrastruktur bagi teater,di dalam esai-esainya yang lain Asrul juga mengutamakan fungsi teater bagi pembentukan Bahasa Indonesia. Bagi Asrul teater adalah alat yang baik sekali untuk penyebaran bahasa Indonesia (1997: 270) di masa-masa transisi pasca-kemerdekaan. Karena menurutnya kelengkapan yang harus dimiliki oleh dialog drama membuat penggunaan bahasa dalam drama jauh lebih kaya dari pada penggunaan bahasa dalam film. Tapi di sisi lain Asrul juga mengkritik drama atau teater yang menggunakan bahasa di luar penggunaan bahasa yang baik, bahasa yang dimaksudnya adalah bahasa keseharian. Berikut ini adalah kutipan lengkapnya:

“Dalam soal bahasa, teater dan film adalah semacam parasit. Ia mempergunakan bahasa yang sudah ada dan menyajikan bahasa dalam bentuk-bentuk yang lumrah dalam suatu zaman. 
Ia merupakan pedagang yang menjual barangnya secara borongan, yang buruk dan yang baik sekali pukul. Ia akan menyebarkan bahasa: segala macam kebiasaan yang baik dalam bahasa dan juga segala macam salah kaprah. Secara kasarnya dapat diambil kesimpulan bahwa dalam soal bahasa, bahasa teater dan film adalah hasil dari penggunaan bahasa masyarakat. Akan baik bahasa yang dipergunakan oleh masyarakat akan lebih baik dan terang pula bahasa yang dipergunakan dalam film dan teater". (Asrul, 1997: 273-274)

Di dalam paragraf terakhir ini penulis akan coba membatasi sekaligus menarik kesimpulan sementara terhadap pemikiran teater Asrul Sani ini. Di mana terdapat tiga poin penting di dalam pemikirannya bagi perkembangan teater Indonesia selanjutnya. Poin-poin itu adalah penerjemahan sastra drama dan teori-metode akting, infrastruktur untuk teater, serta penggunaan dan pembentukan Bahasa Indonesia di dalam teater.

\section{Pembacaan Pascakolonial pada Teater Indonesia Versi Asrul}

Karena teater modern versi Asrul ini akan dibaca melalui perspektif pascakolonial, sangat penting untuk mempermasalahkan dan mencari titik atau relasi kekuasaan dalam membaca perjalanan pemikiran-sikap Asrul yang begitu banyak meng-apropriasi ${ }^{11}$ kebudayaan, khususnya literatur Barat ke Indonesia (pra-pasca kedaulatan). Sebab dalam perspektif pascakolonial,

“...literatur adalah suatu "zona kontak" yang penting, di mana "transkulturasi" terjadi dalam kompleksitasnya. Litera- tur ditulis balik oleh penjajah maupun oleh yang dijajah itu dalam prosesnya seiring menyerap, mengambil, dan penulis aspek-aspek dari budaya "lain", menciptakan genre, gagasan-gagasan, dan identitas-identitas baru. Akhirnya, literatur juga merupakan sarana penting untuk mengambil, membalikkan atau menantang sarana-sarana dominan penggambaran dan ideologi-ideologi kolonial". (Lomba, 2000: 92-93)

Foulcher mengatakan bahwa pembentukan karakter Asrul dan Angkatan'45 ini terjadi lewat interaksi dan dengan kebudayaan Eropa melalui pergaulannya di majalah dan penerbitan Belanda yang meletakkan dasar bagi suatu daya penglihatan terhadap kemandirian identitas kultural berdasarkan dasar-dasar yang dianggap sah dan dapat berlaku secara internasional (1997:110) dan mengambil pilihan untuk menjadi pembebas atau sang modernis di antara 'kolaborasi' dan 'resistensi'di masa panasnya anti-kolonial yang juga sungguh-sungguh sadar terhadap motif-motif politik Belanda. Yang menjadi pertanyaan di sini adalah: Apakah dengan menjadi pembebas atau sang modernis, Asrul dan Angkatan'45 ini, sebenarnya bebas untuk apa? Untuk siapa? Lalu pertanyaan ini dijawab secara imajiner oleh Asrul, ia mungkin mengatakan seperti ini: untuk dunia! untuk pembangunan manusia, untuk pembangunan 'manusia Indonesia' setelah 'kemerdekaan' di panggung dunia.

Melalui jawaban imajiner tersebut, penulis menaruh pentingnya konteks pembacaan sastra dan pascakolonial. Mengingat dalam pembahasan di atas, Foulcher, menyebutkan bahwa karakter Asrul dan Angkatan'45 dipengaruhi, 
dibentuk, dan dimainkan oleh kalangan intelektual-sastrawan Belanda. Karena dalam konteks sastra dan pascakolonial tekstualitas menjadi penting sebagai bagian dari wacana kolonial maupun sebagai bagian dari perlawanan. Sebab, kolonialisme bukan hanya berwujud penindasan fisik, tapi juga penindasan dan kolonisasi alam pikir. Apalagi Asrul mengalami semua itu secara langsung. Tak dapat dipungkiri bahwa ke-wargadunia-annya adalah hasil penyerapan dari berbagai keterlibatannya dengan zona kontak itu. Khususnya, kanonisasi kehebatan dan humanisme budaya Eropa, yang mengedepankan manusia tadi. ${ }^{12}$ Manusia yang dalam istilah Asrul adalah "manusia yang sebenarnya dengan segala kemungkinan dan kemustahilannya, dan hak-haknya untuk memperjuangkan bentuk hidup atas dasar kebenaran sendiri" (1997:252)(th: hal). Tak heran jika Asrul banyak menerjemahkan (dalam proyek ATNI atau DKJ) karyakarya sastra drama dengan pengarang: W. Shakespeare, Rabindranath Tagore, Emmanuel Robles, Federico Garcia Lorca, Anthon Chekhov, Nikolai Gogol, Albert Camus, Jean Paul Sartre, Henrik Ibsen, August Strindberg, Moliere, Jean Anouilh, Bertolt Brecht, Francoise Sagan, Alexander Ostrovsky, George Bunchner, W. Butler Yeats, William Congreve, Karel Capek, Tanked Dorst, Alexandre Dumas, Edward Albe, T.S Eliot, Elmer Rice, Frank Wedekind, Jean Genet, Jean Giraudoux, David Giraudon, Gerhard Hauptmann, Friedrich Hebbel, Alfred de Musset, Arthur Miller, Eugene O'Neil, Ferenc Molnar, Harold Pinter, Luigi Pirandello, Jean Racine, Sean O'Casey, Victor Sardon, Arthur Schnitzler, Eugene Scribe, George Bernard Shaw, Ivan Turgenev, Leo Tolstoy, Tennessee Williams, Thornton Wilder, Emile Zola. ${ }^{13}$

\section{PENUTUP}

Naskah sastra drama dari karya nama-nama pengarang di atas sampai hari ini kurang-lebih masih tersimpan, dipakai, dan menjadi standar di ranah dan praktik teater, khususnya perguruan tinggi seni yang mengharuskan dirinya mempunyai ukuran tertentu untuk menghasilkan capaian-capaian penguasaan teori sekaligus praksis teater yang dilembagakan. Dengan menggiring wacana ini ke wacana pendidikan seni atau pun di luar pendidikan seni yang turut membuat standar ini, adalah untuk mencoba menawarkan praktik pembacaan kontekstual (politis dan kultural) di dalam pergaulan tersebut dan untuk juga merangsang meredefinisi-merekonstruksi teks-teks kanon yang diperlukan sebagai ukuran dalam penilaian pencapaian kualitas estetik dan artistik saat ini (khususnya di pendidikan seni).

Konsekuensi dari teks-teks kanon di atas yang diserap Asrul melalui pergaulan intelektualnya sebagai yang berpendidikan juga dipakai untuk pendidikan juga, makadi dalam pendidikan itu mau tidak mau dipunyai ekses ke luar ranah pendidikannya juga. Kalau memang yang menjadi karakter teater pelajar (amatir) adalah 'mutlak berpegangan pada naskah drama untuk main' menjadikan teks kanon ini menjadi regulasi kognitif yang terinternalisasi dan diarfimasi melalui peran pendidikan dan kepercayaannya pada teaternya yang menyumbangkan moralitas kemanusiaan dan bahasa Indonesia yang baik, dalam pengertian membangun moralitas kedalaman nilai-nilai kemanusian, yakni moralitas universalisme Barat (yang padahal partikular Barat). Menurutnya, hal ini bukan hanya sekadar bahasa yang 'bisa 
dilihat dengan mata dan dihayati secara badaniah', yang "persoalannya hanya berputar sekitar uang, makan dan pakaian serta hubungan kekelamin". Sebab Asrul percaya pada pameo "bahasa menunjukan bangsa."14

Kita perlu berani memeriksa dan mengungkap formasi macam apa yang menjadikan teks-teks tertentu dianggap sebagai kanon dan terus berlaku sampai saat ini. Hal ini tentu saja melalui pembacaan sejarah (genealogis), kalau dalam istilah Foulcher terhadap konteks kondisi literatur Indonesia ${ }^{15}$ : "apa yang menyebabkan kita menjadi begini?". "Kebeginian” yang macam apa yang terus bergerak di dalam tubuh wacana dan praktik teater hari ini? Sebab apa yang diinginkan Asrul di dalam teaternya, yakni manusia di luar sastra drama dunia dan teori-metode akting, infrastruktur, serta penggunaan dan pembentukan Bahasa Indonesia di dalam teater, juga sudah bergerak dan memiliki konteks politis-kulturnya masing-masing. Mengingat bahwa teater modern versi Asrul Sani ini lahir di kota Jakarta, yang banyak dipercayai sebagai pusat gejolak dari relasi kekuasaan Belanda-Indonesia. Dan itu semua bukan lantaran hanya sikap teaternya, tapi juga kerena kompleksitas dari berbagai peristiwa dalam lingkungan budaya saat pikiran-pikiran teater Asrul muncul. Sebab yang sedang terjadi atau pun - untuk yang masih percaya kondisi teater kita hari ini baik-baik saja - nantinya teater yang mengalami "kebeginian" ini bukan tidak mungkin kehilangan apresiasi publiknya (atau sedang?) dan menjawab kehilangan itu dengan pragmatisme manajemen seni (pasar), serta memohon-mohon (dengan cara apapun) ke media massa agar ulasan pertunjukannya dimuat. Ketika kita sibuk dengan hal-hal pragmatis tersebut, kita semakin kehilangan daya dan tanggung jawab dalam membaca medan sosial dan kultural kita sendiri, di mana di medan itu terdapat publik, yakni penonton, semacam dwi-tunggal dalam praktik teater kita.

Juga sangat tidak adil bila Asrul dipersalahkan karena pembacaan dalam "kebeginian" dan semacam ramalan konsekuensional di atas. Sebab Asrul dengan segala pemikirannya mempunyai konteks sendiri. Misalnya, apropriasi yang dilakukannya dari penerjemahan literatur dan pemikirannya tentang fungsi teater sekaligus bagaimana membuat infrastruktur baginya. Semua ini karena beban kultural yang dipikulnya selama masa-masa pergolakan meraih kedaulatan menjadikannya mengambil posisi secara politis berada 'di antara' atau dalam istilah Homi Bhabha mengalami ambivalensi. Ambivalensi ini merupakan sikap yang diambilnya dalam bernegosiasi dengan: "motif-motif politik Belanda" dan penolakannya terhadap “ke-indonesia-an" yang nativistik. Dalam sikap Asrul, ambivalensi ini berarti menjadi 'ahli waris yang sah dari kebudayaan dunia' untuk mengisi 'kekosongan sejarah kebudayaan Indonesia' dan memperoleh otoritas pendidikannya yang mungkin dalam kenyataannya tidak disediakan oleh Indonesia sebelum memperoleh kedaulatan misalnya. Bukan tidak mungkin, pemikirannya tentang infrastruktur bagi teater titik awal alasannya ada pada masalah ini.

Maka sebagai penutup, pandangan Chinua Achebe (pengarang Nigeria) yang ingin melihat kata universal dihapus sama sekali dari diskusi-diskusi tentang sastra Afrika dan menjadi sinonim kesempitan berpikir Eropa yang hanya berguna bagi diri mereka sendiri ${ }^{16}$ dan Ngugi wa Thi- 
ong'o (pengarang Kenya) yang menyatakan keheranannya pada gagasan bahwa 'Renaissance' atau 'Pencerahan' Eropa masih bisa diajarkan di beberapa tempat tanpa mengacu pada sejarah kolonial (Lomba, 2000: 84), bisa dijadikan contoh atau rangsangan awal untuk mengganggu kepercayaan satu orang-generasi yang sudah terlembagakan dan menjadi semacam 'tuntunan' generasi selanjutnya. Tentu saja, untuk tidak terjebak nativisme kultural dan esensialismenya di mana pada perkembangannya merupakan hasil dari streotipikasi Barat (misalnya: pariwisata seni). Dengan menutup tulisan ini melalui pandangan dua sastrawan Benua Afrika tersebut, penulis malah mengganggap pencarian sebetulnya baru dimulai. Karena pembacaan terhadap teater yang dibawa Asrul Sani dari Eropa dan Amerika itu juga sebenarnya sudah dilakukan melalui pergaulan teater pada tahun $80-90$-an, hanya saja mungkin pembacaan itu tidak eksplisit dibaca melalui perspektif pascakolonial dan 'hilang' disekitaran wacana pragmatis: kemajuan Teater Indonesia di tengah medan globalisasi media yang datang lebih dekat pada manusia.

\section{CATATAN AKHIR}

1. Untuk pembahasan lebih lanjut mengenai kondisi teater modern Indonesia yang membentuk sebuah generasi "teater sutradara", lihat esai Benny Yohanes, Menyudahi Indonesia: Mencari Teater Dari Bunuh Diri Ideologis, dalam buku Ideologi Teater Modern Kita. Pustaka Gondo Suli, Yogyakatra, tahun 2000. Hal: 12-18.

2. Uraian biografi singkat ini disarikan dari tulisan Ajip Rosidi dalam buku Asrul Sani 70 Tahun, yang diterbitkan Pus- taka Jaya.Hal xi-xxi.

3. Dalam tulisan ini saya tidak akan membahas dan menceritakan lagi apa yang telah dituliskan Jakob mengenai peristiwa-peristiwa penting dalam masa perkembangan tersebut. Saya akan lebih mencoba untuk langsung menohok pada bagian perkembangan sastra terjemahan tahun 1950-an di mana Asrul dan Angkatan '45-nya mempunyai andil besar dalam menyokong untuk kelanjutan pementasan naskah barat oleh Indonesia. Misalnya dalam praktik dari sikap pandangan teater Asrul dan semasa proyek penerjemahan naskah oleh DKJ pada tahun 1970-an, tercatat dalam buku Asrul Sani 70 Tahun, Asrul telah menerjemahkan 100 judul naskah drama Asing (meskipun tidak semua pernah dipentaskan).

4. Asrul, Jakarta, 18 Februari 1950, dalam buku Surat-Surat Kepercayaan, Pustaka Jaya, 1997. Hal 3-4 (untuk selanjutnya buku Surat-Surat Kepercayaan ini disingkat menjadi: SSK)

5. Surat-Surat Kepercayaan adalah buku kumpulan tulisan Asrul Sani yang disunting Ajip Rosidi dan diterbitkan Pustaka Jaya, tahun 1997.Di dalam buku ini juga terdapat Surat Kepercayaan Gelanggang yang ditulis Asrul sebagai sikap kultural atau pandangan dunia para seniman Angkatan' 45.

6. Biografi singkat di atas tentu saja tidak signifikan untuk membaca bagaimana interaksi Asrul dan Angkatan'45 di dalam relasi kehidupan politik dan kebudayaan (literatur) Belanda-Indonesia. Keith Foulcher dalam esainya yang akan dibahas ini mengutip dari esai H.B Jassin "Humanisme Universil" (tahun 1967, yang kemudian dihilangkan dalam edisi revisi tahun 1985). Kelompok Chairil Anwar pertama kali memperoleh saluran resmi 
dalam berekspresi melalui penerbitan majalah kebudayaan Gema Suasana bulan Januari 1948. Dewan redaksinya terdiri dari Asrul Sani, Chairil Anwar, Mochtar Apin, Rivai Apin, dan Bahharudin. Majalah kebudayaan ini diterbitkan oleh percetakan Belanda Opbouw (Pembangoenan). Dan juga pada saat yang sama beinteraksi secara akrab dengan pusat aktivitas lain dalam majalah kebudayaan berbahasa Belanda yang terbit dua mingguan Orientatie yang terbit pada November 1947. Dua penerbitan majalah yang sama-sama diinisiasi oleh Belanda. Kalau dalam majalah $O p$ bouw mereka memiliki tanggung jawab penuh pada pengelolaan uang dan keredaksian, tapi di majalah Orientatie mereka ada dalam relasi (pada awalnya) kepentingan politik Belanda, dalam mendorong pertukaran budaya dan saling pengertian dalam sebuah iklim yang terkarakterisasi dengan perasaan saling bermusuhan dan penuh kecurigaan. Dan semuanya ada di bawah pengarahan pribadi penulis Hindia Belanda Rob Niewenhuys. Sampai pada akhirnya, setelah penyerahan kedaulatan, Niewenhuys berusaha untuk memberikan karakter 'sastera' sepenuhnya pada majalah ini, dalam upaya menjauhkannya dari tujuan propaganda pemerintah Belanda. Hal inimenjadikannya sebagai tempat pertemuan bagi individu-individu yang berasal dari rasa apa pun dalam melihat 'Indonesia sebagai tanah air kebudayaan mereka. Di majalah inilah kelompok Chairil Anwar dijembatani untuk bersentuhan dengan Eropa modern, dalam pengertian penyediaan buku-buku, maupun tempat untuk diskusi. Mereka juga menggiring penulis-penulis Indonesia melalui penerjemahan sejumlah karya sastra Indonesia yang dimuat dalam Orientatie. Dan memainkan peranan dalam hal pembentukan Angkatan '45 sebagai juru bicara revolusi Indonesia yang mempunyai karakter antipati pada motif-motif politik Belanda dan kebudayaan Belanda, sebagaimana tingkat kecurigaan mereka pada gejala nasionalisme kebudayaan. Dari interaksi inilah (menurut saya) awal kelahiran pikiran-sikap kredo Surat Kepercayaan Gelanggang itu lahir dan bergulir menjadi polemik kesusastraan Indonesia.

7. Untuk mendapatkan pengetahuan lebih komprehensif bisa dibaca lebih dalam pada esai Keith Foulcher ini yang juga terdapat di dalam buku Asrul Sani 70 Tahun.Hal: 85-113

8. Fungsi Teater, Budaya Jaya No. 68, 1973. Di ambil dari SKK

9. Medium Yang Disia-siakan, Diterbitkan di Majalah Siasat, 30 Agustus 1953. Diambil dari SKK. (Asrul, 1997: 216)

10. Lihat, Teater Saya Teater Kini, Arifin C. Noer, dalam buku Teater Indonesia: Konsep, Sejarah, dan Problema. Tommy. F Awuy (penyunting), DKJ, tahun 1999, hal. 106-128. Arifin C.Noer sempat membahas sekaligus mengkritik teknik pemeranan ini di dalam esainya. Arifin mengetengahkan konsep inner-activity yang di dalam teori-metode akting Stanilavsky menjadi dasar teorinya. "Di mana seorang aktor harus mempelajari kebudayan yang melatarbelakangi perannya secara lengkap, di samping ia juga harus menangkap secara tepat penafsiran secara fisiologis, sosiologis, dan psikologis, serta hal-hal lain yang berhubungan dengan kebutuhan permainannya. Sungguh suatu kesulitan yang sangat besar bagi seorang aktor Indonesia yang kebetulan dari 'kelas bawah' (kelas yang jauh dari pergaulan dan sentuhan cara Belanda) untuk bisa menangkap lalu menghayati kebiasaan sehari-hari dari tokoh asing yang akan di- 
mainkannya."

11. Apropiasi adalah menjadikan sesuatu yang asing milik sendiri, "melalui proses peyerapan dan pembentukan ulang. Agar dapat menanggung beban pengalaman kultural seseorang" (Bill Ashcroft, Gareth Griffths, Helen Tiffin, Menelanjangi Kuasa Bahasa, Qalam, hal. 42)

12. Untuk memahami lebih jauh tentang hubungan pascakolonialisme dan humanisme, lihat: Leela Gandhi, Postcolonial Theory A Critical Introduction, 1998, hal. 31-53. Saya akan mengutip sedikit di sini. Leela menyebutkan, "dalam memahami hubungan yang menjengkelkan antara poskolonialisme dengan humanisme, sangat perlu untuk mengenali bahwa kajian poskolonial melahirkan dua pendekatan yang nyata secara kronologis, atas sejarah dan akibat-akibat humanisme. Perta$m a$, berkaitan dengan humanisme sebagai progam budaya dan pendidikan yang berawal dari kebangkitan Itali sekitar pertengahan abad ke-16 dan berkembang dengan cepat menjadi wilayah kajian yang sekarang kita kenal sebagai ilmu kemanusian. Kedua, pendekatan postrukturalis membawa makna dan kronologi yang lebih tepat dengan gagasan humanisme. Kajian ini mengidentifikasi humanisme dengan teori subjektivitas pengetahuan yang secara filosofis dikembangkan oleh Bacon, Descartes, dan Locke, dan dari sisi ilmu pengetahuan disarikan oleh Galileo dan Newton. Revolusi filosofis dan pengetahuan ini disampaikan untuk menemukan pemenuhannya yang sesuai di abad ke-18 di mana ia diterima sebagai Pencerahan atau Aufklarung."

13. Saya sengaja menyebutkan nama-nama pengarang yang karyanya diterjemahkan Asrul di dalam tulisan saya, karena menurut saya penting untuk menunjukkan informasi/data yang sudah sulit dicari. Untuk informasi lain tentang berapa jumlah karya sastra perpengaran [?] yang diterjemahkan Asrul bisa dilihat di buku Asrul Sani 70 Tahun, Hal. 306-308.

14. Lihat SKK, Bahasa Indonesia dalam Film dan Teater, Hal.276.

15. Lihat, Keith Foulcher, In Search of the Postcolonial in Indonesian Literature, di dalam Clearing A Space: Kritik Pasca Kolonial tentang Sstra Indonesia Modern.

16. Lihat, Chinua Achebe, Colonialist Criticism, Morning Yet on Creation Day. Heinemann: London dll, 1977, 1-18

\section{DAFTAR PUSTAKA}

Afrizal Malna dan Hare Rumemper (Ed). 1989 Beberapa Pemikiran Tentang Pementasan Naskah Barat Oleh Teater Indonesia. Jakarta: Goethe-Institut.

Ajip Rosidi (penyunting),

1997 Asrul Sani 70 Tahun (Penghargaan dan Penghormatan). Jakarta: Pustaka Jaya.

Ania Lomba.

2003 Kolonialisme/Pascakolonialisme. Yogyakarta:Bentang Budaya.

Ashcroft, Bill, Gareth Griffths, Helen Tiffin 2003 Menelanjangi Kuasa Bahasa. Yogyakarta: Qalam.

Asrul Sani dan Ajip Rosidi (penyunting) 1997 Surat-Surat Kepercayaan. Jakarta: Pustaka Jaya.

F. Tommy Awuy (penyunting)

1999 Teater Indonesia: Konsep, Sejarah, 
dan Problema. Jakarta: Dewan Kesenian.

Foulcher, Keith dan Tony Day (Ed).

2006 Clearing A Space: Kritik Pasca Kolonial tentang Sastra Indonesia Modern. Jakarta: Yayasan Obor

Gandhi, Leila.

1998 Postcolonial Theory: A critical Intruduction, St. Leonards: Allen \& Unwin.

Lephen Purwarahaja (Penyunting).

2000 Ideologi Teater Modern Kita. Yogyakarta: Pustaka Gondho Suli. 